ARTICLE

DOI: $10.1038 /$ s41467-018-06319-6

\title{
Vegetation response to exceptional global warmth during Oceanic Anoxic Event 2
}

Ulrich Heimhofer ${ }^{1}$, Nina Wucherpfennig ${ }^{1}$, Thierry Adatte ${ }^{2}$, Stefan Schouten ${ }^{3,4}$, Elke Schneebeli-Hermann (D) ${ }^{5}$, Silvia Gardin ${ }^{6}$, Gerta Keller ${ }^{7}$, Sarah Kentsch ${ }^{1} \&$ Ariane Kujau (D) $^{8}$

The Cenomanian-Turonian Oceanic Anoxic Event (OAE2; 94.5 million years ago) represents an episode of global-scale marine anoxia and biotic turnover, which corresponds to one of the warmest time intervals in the Phanerozoic. Despite its global significance, information on continental ecosystem response to this greenhouse episode is lacking. Here we present a terrestrial palynological record combined with marine-derived temperature data (TEX ${ }_{86}$ ) across an expanded OAE2 section from the Southern Provençal Basin, France. Despite high $\mathrm{TEX}_{86}$-derived temperature estimates reaching up to $38^{\circ} \mathrm{C}$, the continental hinterland did support a diverse vegetation, adapted to persist under elevated temperatures. $\mathrm{A}$ transient phase of climatic instability and cooling during OAE2 known as Plenus Cold Event (PCE) is marked by the proliferation of open, savanna-type vegetation rich in angiosperms at the expanse of conifer-dominated forest ecosystems. A rise in early representatives of Normapolles-type pollen during the PCE marks the initial radiation of this important angiosperm group.

\footnotetext{
${ }^{1}$ Institute for Geology, Leibniz Universität Hannover, 30167 Hannover, Germany. ${ }^{2}$ Institute of Geology and Palaeontology, Université de Lausanne, 1015 Lausanne, Switzerland. ${ }^{3}$ Royal Netherlands Institute for Sea Research (NIOZ), Department of Marine Microbiology and Biogeochemistry, Utrecht University, 1790 AB Den Burg, Texel, The Netherlands. ${ }^{4}$ Department of Earth Sciences, Utrecht University, 3584 CS Utrecht, The Netherlands. ${ }^{5}$ Paleontological Institute and Museum, Universität Zürich, 8006 Zürich, Switzerland. ${ }^{6}$ Centre de recherche sur la Paléobiodiversité et les Paléoenvironnements, Université Pierre et Marie Curie Paris 06, 75252 Paris, France. ${ }^{7}$ Department of Geosciences, Princeton University, Princeton 08544 NJ, USA. ${ }^{8}$ GFZ German Research Centre for Geosciences, Telegrafenberg 14473 Potsdam, Germany. Correspondence and requests for materials should be addressed to

U.H. (email: heimhofer@geowi.uni-hannover.de)
} 
P ast time intervals of exceptional climatic warmth, typically associated with elevated $p \mathrm{CO}_{2}$, had profound impacts on floral compositions and biogeographic patterns of continental vegetation ${ }^{1-3}$. Within the overall greenhouse climate characterizing the Mesozoic, the Late Cretaceous Oceanic Anoxic Event (OAE) 2, which spans the Cenomanian-Turonian boundary [94.1 million years ago (Ma)], marks the onset of an extreme phase in ocean temperatures known as the "Cretaceous thermal maximum" 4 . This phase is characterized by one of the highest $\left(>35^{\circ} \mathrm{C}\right)$ proxy data-derived sea-surface temperature (SST) estimates of the last 150 Myrs, which are recorded by both planktonic foraminifera $\delta^{18} \mathrm{O}$ and archaeal membrane lipid-based TEX $_{86}$ data $^{6}$. A significant rise in low- and mid-latitude open ocean SSTs $\left(2-4^{\circ} \mathrm{C}\right)$ and mid-latitude shelf-sea temperatures $\left(4-5^{\circ} \mathrm{C}\right)$ accompanied the onset of OAE2, resulting in the Late Cenomanian-Turonian hothouse $e^{5,7-9}$. Besides the exceptional thermal conditions, the OAE2 (lasting $700-800 \mathrm{kyrs}^{10,11}$ ) is associated with widespread formation of organic-rich deep-water deposits $^{12,13}$, a major positive carbon isotope excursion (CIE) in carbonate and organic carbon reflecting massive burial of ${ }^{13} \mathrm{C}$ depleted carbon ${ }^{14,15}$, and major biotic turnover in marine ecosystems ${ }^{16,17}$.

Despite the outstanding position of OAE2 as one of the most remarkable events of the Mesozoic ${ }^{18}$, the responses of terrestrial ecosystems and continental flora to the changes of the global climate system remain largely unexplored. To date, just a few isolated plant macrofossil discoveries have been reported from the organic-rich Bonarelli Level, which is the sedimentary expression of the OAE2 in Marche-Umbria, Italy ${ }^{19}$. Microfloral evidence is essentially lacking due to the overwhelming predominance of amorphous kerogen in most marine OAE2 black shales, diluting any continent-derived spore-pollen signal. However, based on a shift in the $\delta^{13} \mathrm{C}$ signature of leaf-wax $n$-alkanes, a change from $\mathrm{C} 3$ to $\mathrm{C} 4$-dominated low-latitude vegetation triggered by a $p \mathrm{CO}_{2}$ drop has been proposed ${ }^{20}$ for the early phase of OAE2. According to theoretical considerations ${ }^{21}$, the exceptional warmth that prevailed during Late Cenomanian-Turonian times may have exceeded the heat tolerance of continental ecosystems, which potentially resulted in widespread vegetation dieback.

Here we present a high resolution and taxonomically differentiated spore-pollen record across a stratigraphic interval correlating to the OAE2. The record is from an expanded marine section (Cassis) from the Southern Provençal Basin (SPB) of S' France (Fig. 1) and has been analyzed for biostratigraphy,

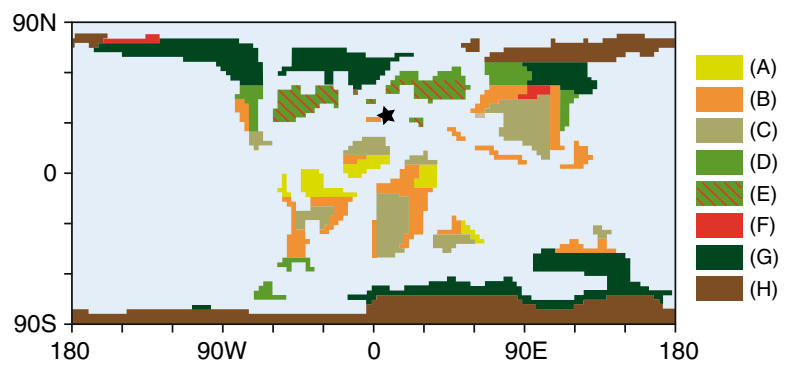

Fig. 1 Palaeogeographic map illustrating Cenomanian-Turonian biome distribution. Palaeo-map is modified after ref. 48 and includes the extent of the Normapolles palynofloral province 29 . Color code representing (A) tropical moist, open canopy mixed forest with shrub understory; (B) savanna-type dry low understory with sparse trees; (C) deciduous dry/ warm shrubland; (D) mid-latitude evergreen closed canopy conifer forest; (E) Normapolles province; (F) evergreen wet/cool shrubland; (G) highlatitude moist, open canopy forest with shrub understory; $(\mathbf{H})$ boreal closed canopy conifer forest. Asterisk marks approximate location of the Southern Provençal Basin palynology, $\mathrm{TEX}_{86}$ and stable carbon isotopic composition of carbonates and organic materials. Stratigraphic assignment of the section is based on existing ammonite data ${ }^{22}$ combined with new information from planktonic foraminifera, calcareous nannoplankton, and carbon isotopes of bulk carbonate, organic matter and plant wax-derived long-chain $n$-alkanes.

\section{Results}

Stratigraphy. The $\sim 235 \mathrm{~m}$ thick Cassis section represents a heterolithic succession with its lowermost part being composed of clays and marls overlain by (in part) turbiditic sandstones (0.0$19.7 \mathrm{~m}$ ). An exposure gap in the outcrop separates the siliclastic facies from a conspicuous limestone slope deposit characterized by intense slumping and disintegration (33.4-46.1 m). Above another exposure gap, the main part of the section is continuously accessible (55.8-236.0 m) and consists of homogenous marls with intercalated bundles of nodular limestone together representing basinal facies. Existing ammonite data combined with new biostratigraphic results constrain this section to the Upper Cenomanian-Lower Turonian ${ }^{22}$ (Supplementary Note 1). This age assignment is further corroborated and refined by carbon isotope data, which show a characteristic positive CIE revealing an initial high-amplitude positive peak (a) followed by a trough interval, which gives way to a plateau with two consecutive peaks (b, c) (Fig. 2). The characteristic pattern of the CIE is mimicked in the $\delta^{13} \mathrm{C}_{\text {org }}$ signature of bulk organic matter (Supplementary Fig. 1) and corroborated by the isotopic composition of longchain $n$-alkanes derived from plant leaf-wax. Backed by highresolution biostratigraphic data, the CIE evolution can be closely correlated with the reference carbon isotope record from Eastbourne, $\mathrm{UK}^{23,24}$ (Fig. 2). The significantly increased $\delta^{13} \mathrm{C}_{\text {carb }}$ values of the CIE peak (a) at Cassis $(6.0 \%$ ) compared to Eastbourne $(4.8 \%$ ) may reflect a shift in the dominant carbonate source in the SPB during this particular interval. In fact, the Calcaires du Corton Fm. corresponds to a calcareous unit composed of upper slope deposits, which can be traced toward the shoalwater carbonate platform bordering the SPB to the north where similarly high $\delta^{13} \mathrm{C}_{\text {carb }}$ signatures are observed in OAE2equivalent platform limestones ${ }^{25}$. Carbonate carbon isotope signatures $>6.0 \%$ o for the OAE2 CIE are also described from the epeiric Iberian seaway ${ }^{26}$ and may reflect variations in the aragonite content of the periplatform ooze exported from the adjacent platform ${ }^{27}$. The correlation thus reveals very good stratigraphic coverage of the uppermost Cenomanian-Turonian at Cassis with an expanded $200 \mathrm{~m}$ thick OAE2 interval (Fig. 2). High sedimentation rates accompanied by increased input of continental organic debris in a transtensive geotectonic setting 28 may have prevented the accumulation of black shales enriched in marine-derived organic carbon in the SPB.

Palynology. At Cassis, high numbers of inaperturate and bisaccate gymnosperm pollen (avg. $=48.2 \%$ ) are essentially produced by Araucariaceae and Cupressaceae-type plants (Araucariacites spp.; Inaperturopollenites spp.) and Cheirolepidiaceae (Classopollis spp.) with subordinate contributions from Pinaceae (Cerebropollenites spp.) and Podocarpaceae (Podocarpidites spp.). Other gymnosperms, including cycads-ginkgophytes (Cycadopites spp.), gnetaleans (Ephedripites spp.), and seed ferns (Alisporites spp.) are quantitatively of minor importance (avg. $=2.5 \%$ ). Spores produced by a diverse assemblage of ground ferns and fern allies occur in moderate quantities (avg. $=12.8 \%$ ). The assemblage contains a variety of eudicotyledonous angiosperm pollen represented by various tricolporate and triporate types, the majority of which can be assigned to early forms of the 


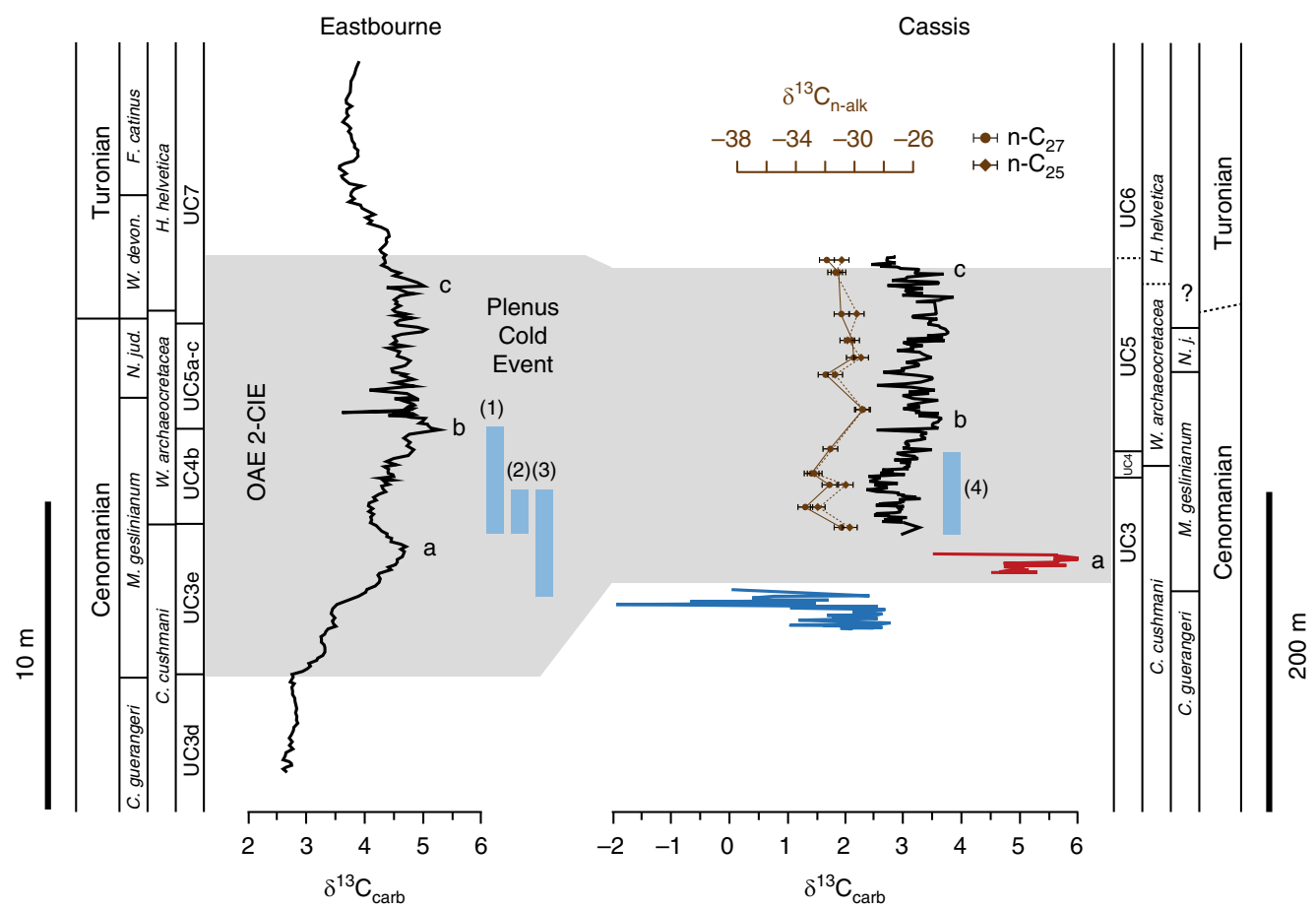

Fig. 2 Bio- and chemostratigraphic correlation. Carbon isotope trend from Cassis, S' France is compared with the European reference section at Eastbourne, Sussex, UK ${ }^{23,24}$. Calcareous nannofossil zonation of Eastbourne after ref. ${ }^{56}$. Planktic foraminiferal biozonation of Eastbourne after ref. ${ }^{69}$. Lowercase letters correspond to principal carbon-isotope peaks identified in the Eastbourne record ${ }^{24}$. Stratigraphic positions of the Plenus Cold Event (PCE) according to ( 1 ) $53,(2)^{70},(3)^{13}$ with (4) representing supposed PCE position at Cassis. Color-code of the Cassis carbon-isotope record corresponds to lithostratigraphic formations 22,28 with blue $=$ Grès de l'Anse Sainte Magdeleine Fm., orange = Calcaires du Corton Fm., black = Marnes de I'Anse de l'Arène Fm. Carbonisotope stratigraphic trend of plant-derived leaf-wax $n$-alkanes $\left(n-C_{25} ; n-C_{27}\right)$ is restricted to the Marnes de l'Anse de l'Arène Fm. $\delta^{13} C$ values of individual $n$-alkanes are the means of duplicate runs $(\sigma= \pm 0.5 \%$ o $)$ expressed versus VPDB. Gray area represents the stratigraphic interval covered by the OAE2 carbon isotope excursion 24,54 . Note the expanded thickness of the OAE2 in the Cassis record

Normapolles complex (predominantly Atlantopollis and Complexiopollis groups; avg. $=18.9 \%$ ) (Supplementary Fig. 2).

Based on stratigraphic variations in relative spore-pollen abundances, six characteristic assemblage zones (AZ I-VI) are differentiated from base to top (Fig. 3). A pre-CIE assemblage (AZ I, 6.5-18.5 m) shows the lowest number of individual taxa (avg. $=30.2)$ and a moderately high gymnosperm to angiosperm $(\mathrm{G} / \mathrm{A})$ ratio (avg. $=0.65)$ with the angiosperm component being dominated by non-Normapolles-type pollen. Among conifer pollen, relatively high abundances of Cerebropollenites spp. (avg. $=7.3 \%$ ) are paralleled by low Inaperturopollenites spp. content (avg. $=9.5 \%$ ). The overlying assemblage (AZ II, 34.7-45.2 m) corresponds to the first build-up phase (peak a) of the CIE and shows increased total taxa counts (avg. $=39.9)$. An increase in Normapolles-type angiosperm pollen results in slightly lower G/ A-ratios (avg. $=0.62$ ). Conifer-derived Inaperturopollenites spp. remain similar (avg. $=10.6)$ but show a marked increase toward the top of AZ II reaching up to $22.9 \%$. Above, the trough-shaped CIE interval corresponds to an assemblage (AZ III, 57.1-110.8 m) characterized by stable numbers of taxa $($ avg. $=40.1)$ and a low dominance index with average $\mathrm{D}$ values of 0.06 indicating a high degree of ecological evenness of the floral association. Increased abundances of Normapolles-type pollen (e.g., A. microreticulatus) are paralleled by low conifer pollen contents (e.g., Inaperturopollenites spp.) resulting in comparatively low G/A-ratios (avg. $=0.55)$. The onset of peak (b) is again characterized by an assemblage rich in conifer-derived grains and low angiosperm pollen (AZ IV, 114.2-143.2 m) with increased G/A-ratios $($ avg. $=0.70)$ and high dominance index $($ avg. $=0.09)$. Another increase in Normapolles-type pollen marks the overlying assemblage (AZ V, 146.3-149.4 m) which shows the lowest
G/A-ratios (avg. $=0.41$ ) paralleled by low D values of 0.06 . Above, the upper part of the CIE plateau up to peak (c) corresponds to the topmost assemblage (AZ VI, 156.7-225.3 m). Here, the strong dominance of a few abundant conifer-derived pollen (with Inaperturopollenites spp. reaching up to 31.8\%; avg. $=20.4 \%)$ causes substantially higher G/A-ratios (avg. $=0.77)$ and higher dominance indices (avg. $=0.12$ ). Calculated origination and extinction records show very low values and the rangethrough diversity comparatively high and stable values throughout the studied interval, which are illustrating the absence of major land plant extinction during OAE2. Increased values at the base of the origination record and at the top of the extinction record, as well as reduced values at the base and the top of the range-through diversity trend are interpreted as consequences of edge effects.

The overall rich and diverse palynological association obtained from Cassis is taxonomically distinctive for a position within the Late Cretaceous Normapolles phytogeographic province ${ }^{29}$. Stratigraphic trends in the distribution of the abovementioned groups and indices are considered to primarily reflect changes in the vegetation structure of the adjacent continental hinterland of the SPB.

$\mathrm{TEX}_{\mathbf{8 6}}$ temperature estimates. SST estimates based on $\mathrm{TEX}_{86}$ show continuously high temperatures $>35^{\circ} \mathrm{C}$ for the SPB during Late Cenomanian-Turonian times with maximum SSTs reaching $38^{\circ} \mathrm{C}$ (Fig. 3). These warm SSTs conform with existing $\mathrm{TEX}_{86}$ studies from early Late Cretaceous mid- and low-latitude sites $^{5,6,8,9}$ and highlight the exceptional temperature regime prevailing during deposition of OAE2. A gradual SST decline is 


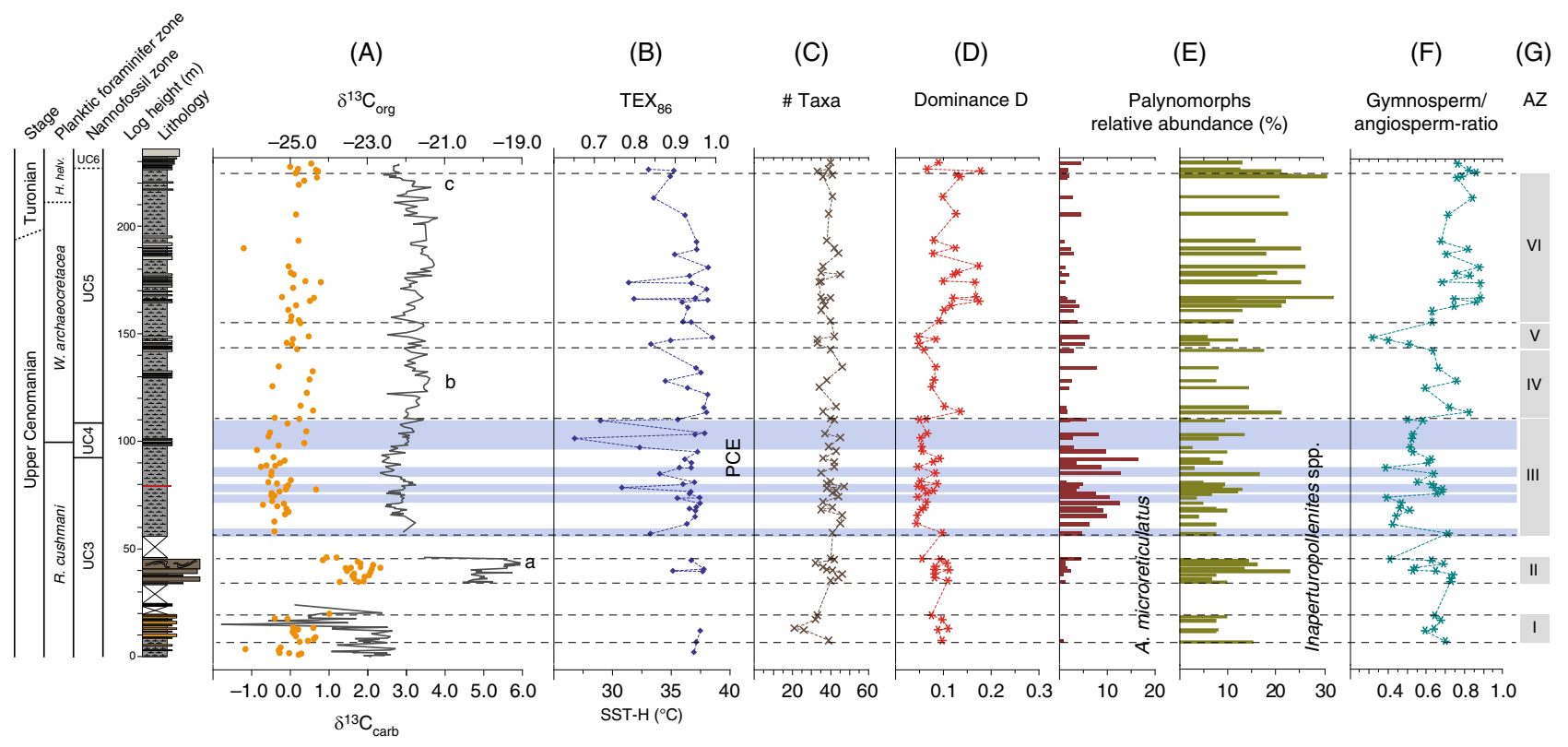

Fig. 3 Terrestrial palynomorph and TEX 86 data across OAE2. Stratigraphic trends in $\delta^{13} \mathrm{C}_{\text {carb }}, \delta^{13} \mathrm{C}_{\text {org, }}$, TEX 86 -derived sea-surface temperatures (SSTs) and evolution of palynofloral diversity and composition across OAE2 at Cassis, S' France. Biostratigraphy and lithological log of Cassis section to the left. (A) Carbon-isotope stratigraphy based on bulk rock carbonate and organic matter; (B) TEX ${ }_{86}$ and SST reconstruction based on TEX ${ }_{86}{ }^{\mathrm{H}}$ calibration; $(\mathbf{C})$ species richness; (D) dominance index; (E) stratigraphic distribution of selected pollen including the Normapolles-type angiosperm pollen Atlantopollis reticulatus and the conifer pollen Inaperturopollenites spp.; (F) ratio of gymnosperm versus angiosperm taxa; (G) assemblage zones (AZs) based on characteristic spore-pollen associations. PCE = Plenus Cold Event. Blue horizontal bands represent individual SST cooling episodes during the PCE

indicated by decreasing $\mathrm{TEX}_{86}$ values characterizing the latest Cenomanian to earliest Turonian at Cassis. In the SPB, the overall pattern of exceptional high temperatures is punctuated by several transient drops towards significantly lower $\mathrm{TEX}_{86}$ values $(<0.8)$, which translate into SSTs below $32{ }^{\circ} \mathrm{C}$. These cooler SST estimates characterize a phase of climatic instability and occur within an interval stratigraphically placed within the upper UC3 and UC4 nannofossil zone, below and close to the $R$. cushmani-W. archaeocretacea zone boundary and corresponds to the trough-shaped segment of the CIE between peaks (a) and (b).

\section{Discussion}

Critically high temperatures have been put forward as a mechanism for the suppression of terrestrial plant and animal life during the end-Permian extinction and basal Triassic events ${ }^{30-32}$. For these intervals, exceptional climatic warmth is considered a first order control for the well-documented turnover in continental vegetation ${ }^{3,33}$. During the Cretaceous thermal maximum, exceptional warmth and associated heat stress have also been suggested to significantly affect plant growth by inhibiting photosynthesis to a certain extent at daytime temperatures ranging between $35^{\circ}$ and $42^{\circ} \mathrm{C}^{21}$. Continental temperatures in this range are considered life-limiting to plants, resulting in serious thermal stress and potential die-off ${ }^{34,35}$. However, the rich and diverse flora reconstructed from palynological datasets across the OAE2 does not support the idea of widespread heat-induced die-off in continental vegetation - at least not in the hinterland of the studied SPB. Despite maximum TEX $6_{86}$-derived SSTs of up to $38^{\circ} \mathrm{C}$ reconstructed for the SPB, the hinterland supported a rich and diverse flora, which is roughly similar in composition to the type of vegetation thriving in Late Cenomanian to Early Turonian times in other parts of the palaeo-European archipelago ${ }^{36,37}$. Mid-latitude terrestrial plant ecosystems were apparently well adapted to the exceptional warm conditions prevailing during the
Cretaceous thermal maximum. The potential effects of temperature extremes might have been more aggravated in continental interior regions of the subtropics and close to the equator, where even higher mean annual surface temperatures are to be expected $^{38}$.

Despite the absence of major plant extinction associated with OAE2, variations in the relative contribution of individual taxa and groups reflect compositional changes in vegetation. High contents of Araucariaceae and Cupressaceae-derived pollen indicate the presence of forest communities composed of large trees forming a dense emergent cover ${ }^{39,40}$. An arborescent habit of Cretaceous araucarioids is supported by abundant fossil wood finds from midlatitudes ${ }^{41}$ and in line with the growth habit of modern Araucaria types $^{42}$. Together with high pollen abundances produced by Pinaceae, Podocarpaceae and xerophytic Cheirolepidiceae, this type of assemblage (AZ II, IV, and VI) is interpreted to reflect mixed forest dominated by arborescent conifers with an only moderate angiosperm component, which grew in mesic habitats with moderate availability of moisture. Such conifer-dominated ecosystems prevailed during episodes of increased $\delta^{13} \mathrm{C}$ values including the first build-up (peak a, AZ II), the second build-up (peak b, AZ IV) and upper plateau phase (AZ VI) of the CIE. During the trough-shaped CIE segment and between peaks $b$ and $c$, conifer forests were replaced by more diverse, angiosperm-rich vegetation with increased contents of Normapolles-derived pollen (AZ III and V). Late Cenomanian taxa assigned to Atlantopollis and Complexiopollis are the first representatives of the Normapolles complex ${ }^{36,43}$, an angiosperm group, which dominated mid-latitude northern hemisphere assemblages during the Late Cretaceous and Early Cenozoic. Based on in-situ findings in fossil flowers, pollen of the Normapolles-type is related to core Fagales ${ }^{44}$. The thick, often multi-layered exine and complex apertures indicate anemophily ${ }^{45}$ and are considered adaptions to open vegetation with widely spaced trees under more dry to seasonally dry climates ${ }^{46}$. During the late Cenomanian, Normapolles-producing angiosperms were probably small nonwoody plants or shrubs forming part of a xerophytic savanna-type 


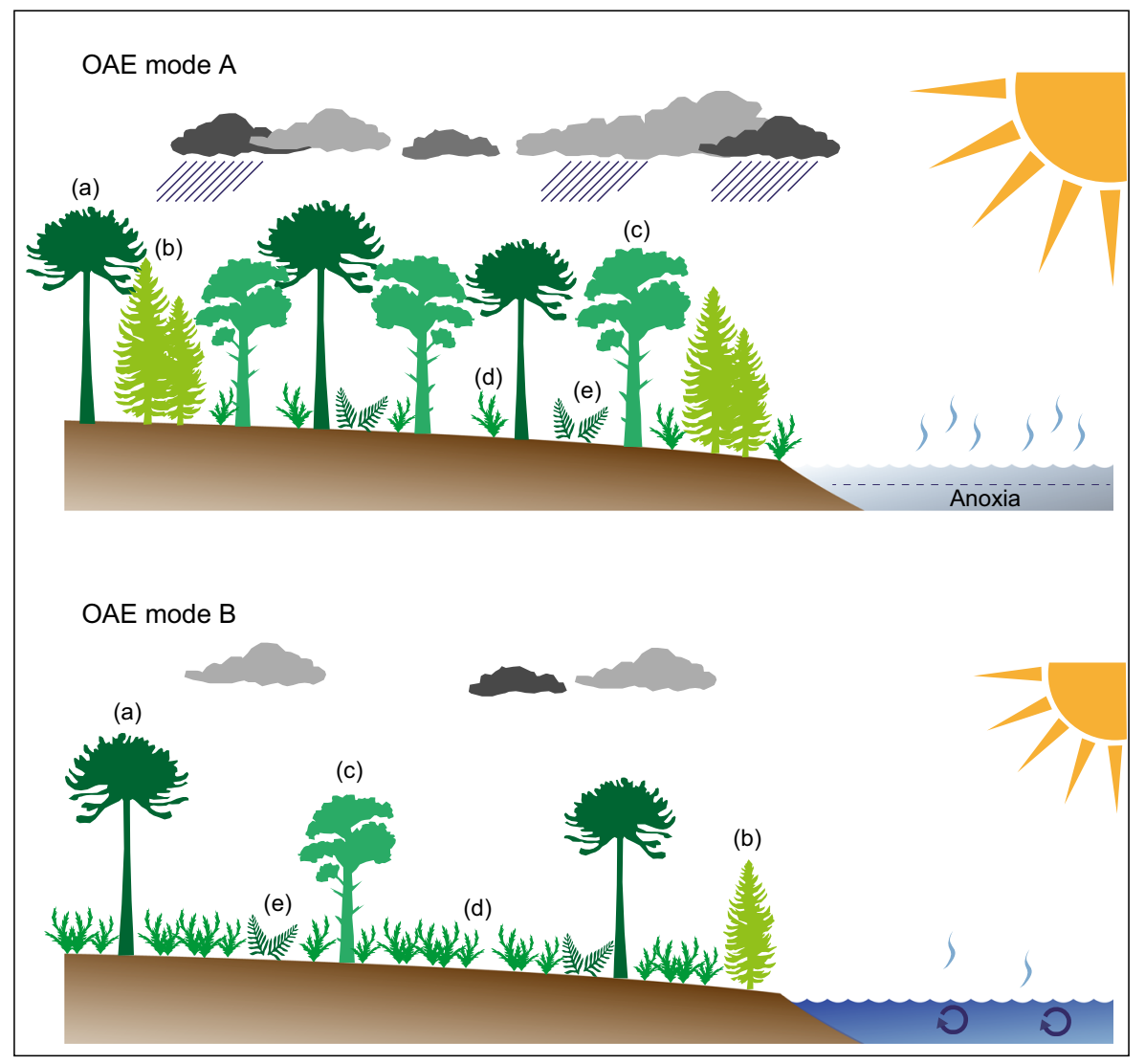

Fig. 4 Tentative changes in mid-latitude vegetation patterns during OAE2. During OAE mode A (e.g. represented by AZ II, IV and VI), the prevailing climate was characterized by exceptional warmth and high moisture availability, giving way to conifer-dominated forests with moderate angiosperm contribution. During OAE mode B (AZ III and V), climatic conditions were cooler and less humid resulting in an open, savanna-type vegetation community with increased abundances of Normapolles-producing angiosperms. (a) Araucariaceae, (b) other conifers incl. Cheirolepidiaceae, (c) Cupressaceae, (d) angiosperms incl. Normapolles-producing forms, (e) ferns

vegetation 47,48 _ a view supported by the rarity of fossil dicot wood in Cenomanian mid-latitude strata from Europe ${ }^{49}$. Accordingly, the palynological record across OAE2 shows changing proportion of arborescent conifer forests (reflecting more mesic conditions) and more open, non-arborescent, angiosperm-rich vegetation.

Fluctuations in the overall climatic patterns during OAE2 have been reported earlier based on marine-derived proxy data. Exceptional climatic warmth associated with OAE2 is considered to have caused accelerated hydrological cycling, enhanced weathering and a generally more humid climate $e^{9,50-52}$. Phases of enhanced moisture availability may have fostered the spread of mesic conifer-dominated forest ecosystems during the onset and later phase of OAE2. Such warm and humid conditions were punctuated by a series of pronounced climatic coolings during the so-called Plenus Cold Event, PCE $^{53,54}$. The PCE represents a phase of climatic instability and is characterized by several shortlasting SST drops and increases in the range of $2.5-11^{\circ} \mathrm{C}^{5-13}$ and paralleled by the southward migration of boreal fauna ${ }^{55}$. Climatic instability was accompanied by a shift towards significantly drier conditions in northern hemisphere mid-latitudes ${ }^{9}$. Stratigraphically, the main pulse of the PCE is located above the first CIE build-up (peak a) at Eastbourne ${ }^{54}$, where it corresponds approximately to the boundary between the R. cushmani and $W$. archaeocretacea zones and UC3 to UC4 transition, respectively ${ }^{56}$. At Cassis, the PCE is expressed in a series of several transient drops of $\mathrm{TEX}_{86}$-derived SSTs below $32^{\circ} \mathrm{C}$ with the strongest SST decline occurring within the upper part of the CIE trough interval (Fig. 3), similar to what has been observed elsewhere ${ }^{5}$. This part of the CIE with a shift towards lower $\delta^{13} \mathrm{C}$ values has been related to improved bottom-water oxygenation, enhanced organic carbon remineralization and significant fluctuations in atmospheric $\mathrm{pCO}_{2}{ }^{13,54,57,58}$. In continental mid-latitude settings such as Cassis, this phase of climatic upheaval is characterized by the proliferation of open, savanna-type vegetation rich in angiosperms at the expanse of conifer-dominated forest ecosystems (Fig. 4). Once established, the savanna-type biome was able to persist even during recurrent phases of exceptional warmth in the course of the PCE.

The onset of the Cretaceous thermal maximum including OAE2 took place against the background of a major turnover in global land plant vegetation, namely the rise of angiosperms towards ecological dominance. In mid-latitude settings of North America and Europe, this floral change is marked by the Late Cenomanian radiation of Normapolles-producing plants related to core Fagales ${ }^{43,45}$. In the Cassis record, early representatives of this group show a pronounced increase in the uppermost Cenomanian assemblage zone III, subsequent to their Mid- to Late Cenomanian origination $^{36}$. Within the overall warm and humid greenhouse conditions characterizing OAE2, a transient shift towards relatively drier climates and punctuated cooling during the PCE may have fostered a first spread of Normapolles-type angiosperms, which henceforward became a very diverse and successful group dominating mid-latitude plant ecosystems throughout the Late Cretaceous to Early Cenozoic for more than 50 Ma.

\section{Methods}

Stable isotope analyses of carbonate and organic carbon. Measurements of stable carbon and oxygen isotopes of sedimentary carbonates were carried out on 
powdered bulk rock material $(\sim 0.5 \mathrm{mg})$ on a total of 292 samples. Stable isotope analysis was conducted using a Thermo Fisher Scientific Gasbench II carbonate device connected to a Thermo Fisher Scientific Delta V Advantage IRMS, available at the Leibniz University Hannover, Germany. The gas bench uses viscous waterfree $(98 \mathrm{~g} / \mathrm{mol})$ orthophosphoric acid at $72{ }^{\circ} \mathrm{C}$ to release $\mathrm{CO}_{2}$ of the calcite from the sample material $1 \mathrm{~h}$ before the start of the measurement. Repeated analyses of certified carbonate standards (CO-1, NBS-18, NBS-19) show an external reproducibility $\pm 0.08 \%$ for $\delta^{18} \mathrm{O}$ and $\pm 0.06 \%$ or $\delta^{13} \mathrm{C}_{\text {carb. }}$. Values are expressed in conventional delta notation relative to the Vienna-Pee Dee Formation belemnite (VPDB) international standard, in per mil (\%) Stable carbon isotope analyses of bulk organic carbon $\left(\delta^{13} \mathrm{C}_{\text {org }}\right)$ were performed on 117 decarbonated samples. Powdered samples were treated twice with $6 \mathrm{M} \mathrm{HCl}$ for $12 \mathrm{~h}$ to remove any carbonate phases and rinsed subsequently with deionised $\mathrm{H}_{2} \mathrm{O}$ until neutrality was reached. Stable carbon isotope composition of bulk $\mathrm{C}_{\text {org }}$ was determined using an organic elemental analyser (Thermo Scientific Flash 2000) connected online to a Thermo Fisher Scientific Delta V Advantage IRMS, available at the Leibniz University Hannover, Germany. The analytical accuracy and reproducibility is checked by replicate analyses of international standards (NBS 22). Reproducibility was better than $\pm 0.1 \%$ for $\delta^{13} \mathrm{C}_{\text {org }}$. Values are expressed in conventional delta notation relative to the Vienna-Pee Dee Formation belemnite (VPDB) international standard, in per mil (\%o).

Palynology. A total of 67 rock samples from the Cassis section were prepared for palynological analysis by the Geological Survey of North Rhine-Westphalia in Krefeld, Germany. Cleaned, crushed and weighed samples ( 20 to $50 \mathrm{~g}$ ) were treated with $30 \% \mathrm{HCl}$ and $38 \% \mathrm{HF}$ for carbonate and silica removal, respectively. Residues were sieved over a $11-\mu \mathrm{m}$ mesh and mounted on microscope slides, which were analyzed at $\times 200$ and $\times 1000$ magnification. All samples were productive and studied for their particle content (palynofacies) and sporomorph assemblage (spores and pollen), respectively. For the quantification of the spore-pollen assemblage, a minimum of 250 grains were determined per slide (avg. 272 grains) and one entire slide was scanned for rare elements. Five samples did not provide enough sporomorphs to reach the target count of 250 grains. Variations in the spore-pollen assemblage represent normalized frequencies and are reported in percentage [\%] of the total assemblage. Thermally unaltered preservation of organic matter is indicated by the virtually unchanged coloring of the sporomorphs and shows a thermal alteration index $(\mathrm{TAI})<2^{59}$. Preservation of the individual pollen grains varies from moderate to good. Sporomorphs are assigned to floral groups according to their botanical affinity ${ }^{60,61}$.

Biomarker analysis. For TEX 86 analysis, a total of 69 powdered and freeze dried samples (5-10 g dry mass) were extracted with an accelerated solvent extractor, using a 9:1 (v/v) dichlormethane (DCM): $\mathrm{MeOH}$ solvent mixture, 3 times for $5 \mathrm{~min}$. at a pressure of ca. $7.6 \times 10^{6} \mathrm{~Pa}$ and a temperature of $100^{\circ} \mathrm{C}$. The obtained total extracts were rotary evaporated and separated over an activated $\mathrm{Al}_{2} \mathrm{O}_{3}$ column using 9:1 (v/v) hexane:DCM and 1:1 (v/v) DCM:MeOH solvent mixtures into an apolar and polar fraction, respectively. The polar fraction, containing the glycerol dialkyl glycerol tetraether lipids (GDGTs), was dried under a pure $\mathrm{N}_{2}$ flow, dissolved ultrasonically in a 99:1 (v/v) hexane:isopropanol mixture at a concentration of $2 \mathrm{mg} / \mathrm{ml}$ and filtered over an $0.45 \mu \mathrm{m}$ mesh PTFE filter $(\varnothing 4 \mathrm{~mm})$ prior to HPLC/MS analysis. High-performance liquid chromatography/atmospheric pressure chemical ionization mass spectrometry (HPLC/APCI-MS) analyses was be performed on an Agilent 1100 series/Hewlett-Packard 1100 MSD series machine equipped with an auto-injector and HP Chemostation software following ${ }^{62}$.

GDGTs were quantified by integration of peak areas and the TetraEther indeX of tetraethers composed of 86 carbon atoms $\left(\mathrm{TEX}_{86}\right)$ was determined ${ }^{63}$. In order to assess the influence of soil-derived GDGTs on TEX $_{86}$ values, the BIT index ${ }^{64}$ was applied. Samples with BIT index $>0.3$ were excluded from SST reconstruction ${ }^{65}$. Absolute SSTs were reconstructed for 64 samples using $\operatorname{TEX}_{86}{ }^{\mathrm{H}}$ core top calibration equation $5^{66}$, which has a calibration error of $2.5^{\circ} \mathrm{C}$. The analytical error of TEX ${ }_{86}{ }^{\mathrm{H}}$-based SST estimates was $0.07^{\circ} \mathrm{C}$ based on duplicate analysis. We used the $\mathrm{TEX}_{86}{ }^{\mathrm{H}}$ calibration rather than other calibrations ${ }^{67}$ in order to remain consistent with previous literature ${ }^{6}$ and as this has recently been shown to match independent temperature estimates in tropical regions during the Eocene hothouse, the warmest period in the Cenozoic ${ }^{68}$. Although the uncertainty of the calibration used is $2.5^{\circ} \mathrm{C}$, comparisons with other proxy datasets ${ }^{6}$ suggests that $\mathrm{TEX}_{86}$ sometimes can overestimate SSTs, or have a seasonal bias, e.g., toward summer temperatures. Nevertheless, even considering this, the here presented SST estimates of up to $38^{\circ} \mathrm{C}$ do suggest hot tropical temperatures well above $30^{\circ} \mathrm{C}$. A level-bylevel comparison of TEX ${ }_{86}$ values and G/A-ratios based on 42 samples supports a general link between SSTs and gross vegetation patterns (Supplementary Fig. 3).

For compound-specific carbon isotope measurements, apolar fractions were treated using an Ag-Silica column with hexane and subsequently ethyl acetate to gain a mostly $n$-alkane pure fraction, which was evaporated under $\mathrm{N}_{2}$ stream followed by dissolution in $25-50 \mu \mathrm{l}$ hexane. For measuring the $\delta^{13} \mathrm{C}$ composition of individual $n$-alkanes, $1 \mathrm{ml}$ was injected into the gas chromatograph isotope ratio mass spectrometer (Agilent $6890 \mathrm{~N}$ GC coupled to a Thermo Delta V advantage IRMS), equipped with a fuse silica capillary column coated with CP-Sil5, with helium used as a carrier gas. The oven was programmed at a starting (injection) temperature of $70^{\circ} \mathrm{C}$, which rose to $130^{\circ} \mathrm{C}$ at $20^{\circ} / \mathrm{min}$ and then $320^{\circ}$ at $4 \% \mathrm{~min}$, at which it was maintained for $20 \mathrm{~min}$. Values are expressed in conventional delta notation relative to the Vienna-Pee Dee Formation belemnite (VPDB) international standard, in per mil (\%). All biomarker analyses were carried out at the NIOZ (Royal Netherlands Institute of Sea Research, The Netherlands).

\section{Data availability}

All data generated and/or analyzed in this study are included in this published article and its supplementary information file, and are also available from the corresponding author on reasonable request.

Received: 6 February 2018 Accepted: 28 August 2018

Published online: 20 September 2018

\section{References}

1. Jaramillo, C. et al. Effects of rapid global warming at the Paleocene-Eocene boundary on neotropical vegetation. Science 330, 957-961 (2010).

2. McElwain, J., Wade-Murphy, J. \& Hesselbo, S. P. Changes in carbon dioxide during an oceanic anoxic event linked to intrusion into Gondwana coals. Nature 435, 479-482 (2005).

3. Hochuli, P. A., Sanson-Barrera, A., Schneebeli-Hermann, E. \& Bucher, H. Severest crisis overlooked - Worst disruption of terrestrial environments postdates the Permian-Triassic mass extinction. Sci. Rep. 6, 1-7 (2016).

4. Norris, R. D., Bice, K. L., Magno, E. A. \& Wilson, P. A. Jiggling the tropical thermostat in the Cretaceous hothouse. Geology 30, 299-302 (2002).

5. Forster, A., Schouten, S., Moriya, K., Wilson, P. A. \& Sinninghe Damsté, J. S Tropical warming and intermittent cooling during the Cenomanian/Turonian Oceanic Anoxic Event 2: Sea surface temperature records from the equatorial Atlantic. Paleoceanography 22, PA1219 (2007).

6. O'Brien, C. L. et al. Cretaceous sea-surface temperature evolution: constraints from $\mathrm{TEX}_{86}$ and planktonic foraminiferal oxygen isotopes. Earth Sci. Rev. 172, 224-247 (2017)

7. Voigt, S., Gale, A. S. \& Flögel, S. Midlatitude shelf seas in the Cenomanian-Turonian greenhouse world: Temperature evolution and North Atlantic circulation. Paleoceanography 19, PA4020 (2004).

8. Sinninghe Damsté, J. S., Van Bentum, E. C., Reichart, G.-J., Pross, J. \& Schouten, S. A $\mathrm{CO}_{2}$ decrease-driven cooling and increased latitudinal temperature gradient during the mid-Cretaceous Oceanic Anoxic Event 2. Earth. Planet. Sci. Lett. 293, 97-103 (2010).

9. Van Helmond, Na. G. M. et al. A perturbed hydrological cycle during Oceanic Anoxic Event 2. Geology 42, 123-126 (2014).

10. Eldrett, J. S. et al. An astronomically calibrated stratigraphy of the Cenomanian, Turonian and earliest Coniacian from the Cretaceous Western Interior Seaway, USA: implications for global chronostratigraphy. Cretac. Res. 56, 316-344 (2015).

11. Li, Y.-X., Montañez, I. P., Liu, Z. \& Ma, L. Astronomical constraints on global carbon-cycle perturbation during Oceanic Anoxic Event 2 (OAE2). Earth. Planet. Sci. Lett. 462, 35-46 (2017).

12. Schlanger, S. O., Arthur, M. A., Jenkyns, H. C. \& Scholle, P. A. The Cenomanian-Turonian Oceanic Anoxic Event, I. Stratigraphy and distribution of organic carbon-rich beds and the marine $\delta^{13} \mathrm{C}$ excursion. Geol. Soc. Lond. Spec. Publ. 26, 371-399 (1987).

13. Jarvis, I., Lignum, J. S., Gröcke, D. R., Jenkyns, H. C. \& Pearce, M. A. Black shale deposition, atmospheric $\mathrm{CO}_{2}$ drawdown, and cooling during the Cenomanian-Turonian Oceanic Anoxic Event. Paleoceanography 26, PA3201 (2011).

14. Arthur, M. A., Dean, W. E. \& Pratt, L. M. Geochemical and climatic effects of increased marine organic carbon burial at the Cenomanian/Turonian boundary. Nature 335, 714-717 (1988).

15. Tsikos, H. et al. Carbon-isotope stratigraphy recorded by the Cenomanian-Turonian Oceanic Anoxic Event: correlation and implications based on three key localities. J. Geol. Soc. Lond. 161, 711-719 (2004).

16. Fischer, V., Bardet, N., Benson, R. B. J., Arkhangelsky, M. S. \& Friedman, M. Extinction of fish-shaped marine reptiles associated with reduced evolutionary rates and global environmental volatility. Nat. Commun. 7, 1-11 (2016).

17. Monnet, C. The Cenomanian-Turonian boundary mass extinction (late Cretaceous): new insights from ammonoid biodiversity patterns of Europe, Tunisia and the Western Interior (North America). Palaeogeog. Palaeoclim. Palaeoecol. 282, 88-104 (2009).

18. Jenkyns, H. C. Geochemistry of oceanic anoxic events. Geochem. Geophys 11, Q03004 (2010).

19. Gomez, B. et al. Cretaceous conifers and angiosperms from the Bonarelli Level; reassessment of Massalongo's plant fossil collections of "Monte Colle", Lessini Mountains, northern Italy. Cretac. Res. 52, 179-193 (2015).

20. Kuypers, M. M. M., Pancost, R. D. \& Sinninghe Damsté, J. A large and abrupt fall in atmospheric $\mathrm{CO}_{2}$ concentration during Cretaceous times. Nature 399, 342-345 (1999). 
21. Hay, W. W. \& Flögel, S. New thoughts about the Cretaceous climate and oceans. Earth Sci. Rev. 115, 262-272 (2012).

22. Jolet, P., Philip, J., Thomel, G., López, G. \& Tronchetti, G. Nouvelles données biostratigraphiques sur la limite Cénomanien-Turonien. La coupe de Cassis (Sud-Est de la France): Proposition d'un hypostratotype européen. Geobios 34, 225-238 (2001).

23. Paul, C. R. C. et al. The Cenomanian-Turonian boundary at Eastbourne (Sussex, UK): a proposed European reference section. Palaeogeog. Palaeoclim. Palaeoecol. 150, 83-121 (1999).

24. Jarvis, I., Gale, A. S., Jenkyns, H. C. \& Pearce, M. A. Secular variations in late Cretaceous carbon isotopes: a new $\delta^{13} \mathrm{C}$ carbonate reference curve for the Cenomanian-Campanian (99.6-70.6 Ma). Geol. Mag. 143, 561-608 (2006).

25. Floquet, M., Léonide, P., Villier, L., Ackouala, A. P., Blenet, A. Expressions biosédimentaire, diagénétique, géochimique et tectonique de l'événement anoxique Cénomano-Turonien (OAE 2) par les plates-formes carbonatées sud-provençales. Résumé de communication, 13ème Congrès Français de Sédimentologie, Paris (2013).

26. Peyrot, D., Barroso-Barcenilla, F. \& Feist-Burkhardt, S. Palaeoenvironmental controls on late Cenomanian-early Turonian dinoflagellate cyst assemblages from Condemios (Central Spain). Rev. Palaeobot. Palynol. 180, 25-40 (2012).

27. Swart, P. K. \& Eberli, G. The nature of the $\delta^{13} \mathrm{C}$ of periplatform sediments: Implications for stratigraphy and the global carbon cycle. Sed. Geol. 175, 115-129 (2005).

28. Floquet, M., Gari, J., Hennuy, J., Léonide, P., Philip, J. Sédimentations gravitaires carbonatées et silicoclastiques dans un bassin en transtension, séries d'âge Cénomanien à Coniacien moyen du Bassin Sud-Provençal. Field

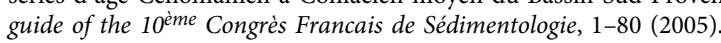

29. Herngreen, G. F. W., Kedves, M., Rovina, L. V., Smirnova, S. B. in Palynology: Principles and Applications Vol. 3 (eds Jansonius, J. \& McGregor, D. C.) 1157-1188 (AASP Foundation, 1996).

30. Sun, Y. et al. Lethally hot temperatures during the early Triassic greenhouse. Science 338, 366-370 (2012).

31. Cascales-Miñana, B. \& Cleal, C. J. The plant fossil record reflects just two great extinction events. Terra Nova 26, 195-200 (2014).

32. Romano, C. et al. Climatic and biotic upheavals following the end-Permian mass extinction. Nat. Geosci. 6, 57-60 (2013).

33. Hermann, E. et al. Terrestrial ecosystems on North Gondwana following the end-Permian mass extinction. Gondwana Res. 20, 630-637 (2011).

34. Berry, J. \& Björkman, O. Photosynthetic response and adaption to temperature in higher plants. Annu. Rev. Plant. Physiol. 31, 491-543 (1980).

35. Huber, M. A hotter greenhouse? Science 321, 353-354 (2008).

36. Méon, H., Guignard, G., Pacltová, B. \& Svobodová, M. Normapolles. Comparison between central and southwestern Europe during the Cenomanian and Turonian: Evolution of biodiversity and paleoenvironment. Bull. Soc. Geol. Fr. 175, 579-593 (2004).

37. Peyrot, D., Barrón, E., Comas-Rengifo, M. J., Barroso-Barcenilla, F. \& FeistBurkhardt, S. Palynological characterization of the Cenomanian/Turonian boundary at Puentedey (Burgos, Spain). Coloq. Pal 58, 101-161 (2008).

38. Poulsen, C. J., Tabor, C. \& White, J. D. Long-term climate forcing by atmospheric oxygen concentrations. Science 348, 1238-1241 (2015).

39. Schrank, E. Pollen and spores from the Tendaguru beds, upper Jurassic and lower Cretaceous of southeast Tanzania: palynostratigraphical and paleoecological implications. Palynology 34, 3-42 (2010).

40. Kershaw, P. \& Wagstaff, B. The southern conifer family Araucariaceae: History, status, and value for paleoenvironmental reconstruction. Annu. Rev. Ecol. Syst. 32, 397-414 (2001).

41. Peralta-Medina, E. \& Falcon-Lang, H. J. Cretaceous forest composition and productivity inferred from a global fossil wood database. Geology 40, 219-222 (2012).

42. Kunzmann, L. Araucariaceae (Pinopsida): aspects in palaeobiogeography and palaeobiodiversity in the Mesozoic. Zool. Anz. 246, 257-277 (2007)

43. Batten, D. J. Stratigraphic, palaeogeographic and evolutionary significance of late Cretaceous and early Tertiary Normapolles pollen. Rev. Palaeobot. Palynol. 35, 125-137 (1981).

44. Friis, E. M., Pedersen, K. R. \& Schönenberger, J. Normapolles plants: a prominent component of the Cretaceous rosid diversification. Plant Syst. Evol. 260, 107-140 (2006).

45. Friis, E. M., Crane, P. R. \& Pedersen, K. R. Early Flowers and Angiosperm Evolution (Cambridge Univ. Press, Cambridge, 2011).

46. Wolfe, J. A. \& Upchurch, G. R. North American nonmarine climates and vegetation during the late Cretaceous. Palaeogeog. Palaeoclim. Palaeoecol. 61, 33-77 (1987).

47. Wing, S. L. \& Tiffney, B. H. The reciprocal interaction of angiosperm evolution and tetrapod herbivory. Rev. Palaeobot. Palynol. 50, 179-210 (1987).

48. Sewall, J. O. et al. Climate model boundary conditions for four Cretaceous time slices. Clim. Past. 3, 647-657 (2007).

49. Philippe, M. et al. Woody or not woody? Evidence for early angiosperm habit from the early Cretaceous fossil wood record of Europe. Palaeoworld 17, 142-152 (2008).
50. Scopelliti, G. et al. High-resolution geochemical and biotic records of the Tethyan 'Bonarelli Level' (OAE2, latest Cenomanian) from the CalabiancaGuidaloca composite section, northwestern Sicily, Italy. Palaeogeog. Palaeoclim. Palaeoecol. 208, 293-317 (2004).

51. Pogge Von, Strandmann, P. A., E., Jenkyns, H. C. \& Woodfine, R. G. Lithium isotope evidence for enhanced weathering during Oceanic Anoxic Event 2. Nat. Geosci. 6, 668-672 (2013).

52. Van Helmond, N. A. G. M. et al. Freshwater discharge controlled deposition of Cenomanian-Turonian black shales on the NW European epicontinental shelf (Wunstorf, northern Germany). Clim. Past. 11, 495-508 (2015).

53. Gale, A. S. \& Christensen, W. K. Occurrence of the belemnite Actinocamax plenus in the Cenomanian of SE France and its significance. Bull. Geol. Soc. Den. 43, 68-77 (1996).

54. Jenkyns, H. C., Dickson, A. J., Ruhl, M. \& Van Den Boorn, S. H. J. M. Basaltseawater interaction, the Plenus Cold Event, enhanced weathering and geochemical change: deconstructing Oceanic Anoxic Event 2 (Cenomanian-Turonian, late Cretaceous). Sedimentology 64, 16-43 (2017).

55. Van Helmond, N. A. G. M. et al. Equatorward phytoplankton migration during a cold spell within the late Cretaceous super-greenhouse. Biogeosciences 13, 2859-2872 (2016).

56. Linnert, C., Mutterlose, J. \& Mortimore, R. Calcareous nannofossils from Eastbourne (southeastern England) and the paleoceanography of the Cenomanian-Turonian boundary interval. Palaios 26, 298-313 (2011)

57. Eldrett, J. S., Minisini, D. \& Bergman, S. C. Decoupling of the carbon cycle during Ocean Anoxic Event 2. Geology 42, 567-570 (2014).

58. Barclay, R. S., McElwain, J. C. \& Sageman, B. B. Carbon sequestration activated by a volcanic $\mathrm{CO}_{2}$ pulse during Ocean Anoxic Event 2. Nat. Geosci. 3, 205-208 (2010)

59. Staplin, F. L. in How to Assess Maturation and Palaeotemperatures, SEPM Short Course 7 (ed Staplin, F. L.) 7-31 (Society of Economic Paleontologists and Mineralogists, 1982).

60. Balme, B. E. Fossil in situ spores and pollen grains: an annotated catalogue. Rev. Palaeobot. Palynol. 87, 81-323 (1995).

61. Abbink, O. A., Van Konijnenburg - Van Cittert, J. H. A. \& Visscher, H. A sporomorph ecogroup model for the northwest European Jurassic-lower Cretaceous: concepts and framework. Geol. Mijnb. 83, 17-31 (2004).

62. Schouten, S., Huguet, C., Hopmans, E. C., Kienhuis, M. V. M. \& Sinninghe Damsté, J. S. Analytical methodology for $\mathrm{TEX}_{86}$ paleothermometry by highperformance liquid chromatography/atmospheric pressure chemical ionization-mass spectrometry. Anal. Chem. 79, 2940-2944 (2007).

63. Schouten, S., Hopmans, E. C., Schefuß, E. \& Sinninghe Damsté, J. S. Distributional variations in marine crenarchaeotal membrane lipids: a new tool for reconstructing ancient sea water temperatures? Earth. Planet. Sci. Lett. 204, 265-274 (2002).

64. Hopmans, E. C., Weijers, J. W. H., Schefuß, E., Herfort, L. \& Sinninghe Damsté, J. S. A novel proxy for terrestrial organic matter in sediments based on branched and isoprenoid tetraether lipids. Earth. Planet. Sci. Lett. 224, 107-116 (2004).

65. Weijers, J. W. H., Schouten, S., Spaargaren, O. C. \& Sinninghe Damsté, J. S. Occurrence and distribution of tetraether membrane lipids in soils: Implications for the use of the TEX ${ }_{86}$ proxy and the BIT index. Org. Geochem. 37, 1680-1693 (2006).

66. Kim, J. H. et al. New indices for calibrating the relationship of the distribution of archaeal isoprenoid tetraether lipids with sea surface temperature. Geochim. Cosmochim. Acta 74, 4639-4654 (2010).

67. Tierney, J. E. \& Tingley, M. P. A Bayesian, spatially-varying calibration model for the TEX 86 proxy. Geochim. Cosmochim. Acta 127, 83-106 (2014).

68. Evans, D. et al. Eocene greenhouse climate revealed by coupled clumped isotope-Mg/Ca thermometry. Proc. Natl Acad. Sci. USA 115, 1174-1179 (2018).

69. Keller, G., Han, Q., Adatte, T. \& Burns, S. J. Palaeoenvironment of the Cenomanian-Turonian transition at Eastbourne, England. Cretac. Res. 22, 391-422 (2001).

70. Voigt, S., Gale, A. S. \& Voigt, T. Sea-level change, carbon cycling and palaeoclimate during the late Cenomanian of northwest Europe; an integrated palaeoenvironmental analysis. Cretac. Res. 27, 836-858 (2006).

\section{Acknowledgements}

This study was supported by DFG grant HE4467/4-1 and 4-2 to U.H. S.S. was supported by the Netherlands Earth System Science Center funded by the Dutch Ministry of Education, Culture and Science. We gratefully acknowledge Marc Floquet, Katharina Müller, Jean Cors, Pauline Rais, and Alexander Brandt for their assistance during field work in SE France and Christiane Wenske for analytical support. We thank Stefan Huck for comments on an earlier version of the manuscript.

\section{Author contributions}

U.H. and T.A. conceived and designed the project with input from S.S. U.H. and T.A. collected the rock samples used in this study. N.W. and U.H. analyzed the palynomorph 
with input from E.S.-H. S.G. and G.K. established the biostratigraphy, S.K. carried out the stable isotope measurements. A.K. carried out the biomarker analyses with the assistance of S.S. U.H. wrote the manuscript with input from all authors.

\section{Additional information}

Supplementary Information accompanies this paper at https://doi.org/10.1038/s41467018-06319-6.

Competing interests: The authors declare no competing interests

Reprints and permission information is available online at http://npg.nature.com/ reprintsandpermissions/

Publisher's note: Springer Nature remains neutral with regard to jurisdictional claims in published maps and institutional affiliations. (c) (i) Open Access This article is licensed under a Creative Commons Attribution 4.0 International License, which permits use, sharing, adaptation, distribution and reproduction in any medium or format, as long as you give appropriate credit to the original author(s) and the source, provide a link to the Creative Commons license, and indicate if changes were made. The images or other third party material in this article are included in the article's Creative Commons license, unless indicated otherwise in a credit line to the material. If material is not included in the article's Creative Commons license and your intended use is not permitted by statutory regulation or exceeds the permitted use, you will need to obtain permission directly from the copyright holder. To view a copy of this license, visit http://creativecommons.org/ licenses/by/4.0/.

(c) The Author(s) 2018 